\title{
Neospora caninum seroprevalence and risk factors for ewes from Santa Catarina Plateau, Brazil
}

\section{Soroprevalência de Neospora caninume e fatores de risco para ovelhas da região Serrana de Santa Catarina, Brasil}

\author{
Anderson Barbosa de Moura ${ }^{1 *}$; Marcelo Felipe Güths²; Juliana Antunes Farias 3 ; \\ Antonio Pereira de Souza ${ }^{1}$; Amélia Aparecida Sartor ${ }^{1}$; \\ Rosiléia Marinho de Quadros ${ }^{1}$
}

\begin{abstract}
Neospora caninum can cause reproductive problems and economic losses in sheep flock. In order to evaluate $N$. canium seroprevalence and to identify risk factors, blood samples were collected from 1,308 ewes at 92 properties in 30 municipalities of Santa Catarina Plateau, southern Brazil. The antibodies against $N$. caninum were detected by Indirect Immunofluorescence Antibody Test (IFAT, $\geq 1: 50$ ) and the seropositive were titrated in serial twofold up to a maximum dilution. Data concerning animal management and information about reproductive problems were obtained from questionnaires. The results were tabulated and analyzed using the Fisher's exact and Chi-Square tests $(\mathrm{P}<0.05)$. Among the 1,308 animals evaluated, $92(7 \%)$ were seropositive to $N$. caninum. The titers observed varied from 1:50 to 1:3200. In $39(42.4 \%)$ properties there was at least one infected animal. Breed $(\mathrm{P}=0.0249)$ and contact with cattle $(\mathrm{P}=0.0491)$ showed correlation with the prevalence of $N$. caninum. No association was found between $N$. caninum serology and reproductive disorders.
\end{abstract}

Key words: Neospora caninum, ewes, seroprevalence, risk factors

\section{Resumo}

A infecção por Neospora caninum em ovelhas pode resultar em problemas reprodutivos. Para avaliar a prevalência da infecção por $N$. caninum, identificar fatores de risco e a existência de correlação entre neosporose ovina e desordens reprodutivas, sangue de 1308 ovelhas em idade reprodutiva foram colhidos em 92 propriedades de 30 municípios do Planalto Catarinense. A detecção de anticorpos contra $N$. caninum foi realizada por meio da Reação de Imunofluorescência Indireta (RIFI, $\geq 1: 50$ ) e as amostras positivas foram analisadas em diluições seriadas de base dois até a titulação máxima reativa. Dados referentes ao manejo dos animais e informações acerca de problemas de ordem reprodutiva foram obtidos por meio da aplicação de questionário. Os resultados foram tabulados e analisados estatisticamente por meio dos testes exato de Fisher e de qui-quadrado $(\mathrm{P}<0,05)$. Dos 1308 animais avaliados, $92(7 \%)$ foram sororreagentes a $N$. caninum. Os títulos observados variaram de 1:50 a 1:3200. Em 39 (42,4\%) propriedades foram identificados ao menos um animal positivo. Raça $(\mathrm{P}=0,0249)$ e contato com bovinos $(\mathrm{P}=0,0491)$ apresentaram correlação com a prevalência para $N$. caninum. Não foi verificada associação entre sorologia para $N$. caninum e desordens reprodutivas.

Palavras-chave: Neospora caninum, ovelhas, soroprevalência, fatores de risco

\footnotetext{
${ }^{1}$ Profs., Centro de Ciências Agroveterinárias, CAV, Universidade do Estado de Santa Catarina, UDESC, Lages, SC, Brasil. E-mail: anderson.moura@udesc.br; antonio.souza@udesc.br; amelia.sartor@udesc.br; rosileia18@hotmail.com

2 Discente de Medicina Veterinária, CAV/UDESC, Lages, SC, Brasil. E-mail: marcelo_guths@hotmail.com

${ }^{3}$ Discente de Doutorado PPGCA, CAV/UDESC, Lages, SC, Brasil. E-mail: juliana0807@hotmail.com

* Author for correspondence
} 


\section{Introduction}

$N$. caninum is an obligate intracellular protozoan belonging to the subfamily Toxoplasmatinae, family Sarcocystidae in the phylum Apicomplexa (MUGRIDGE et al., 1999) which has a heteroxenous life cycle. Its definitive hosts are dogs, coyotes, dingoes and wolves (McALLISTER et al., 1998; GONDIN et al., 2004; KING et al., 2010; DUBEY et al., 2011). Cattle, sheep, goats, horses and deer were found among infected intermediate hosts.

The first report of neosporosis in naturally infected sheep was performed by Dubey et al. (1990). Abortion was observed by Dubey and Lindsay (1990) in experimentally infected sheep with $N$. caninum and McAllister et al. (1996) reported a clinical picture similar to sheep toxoplasmosis and bovine neosporosis. The same was described by Buxton et al. (1997) who found IgM and IgG antibodies in the fetuses of sheep inoculated. Buxton et al. (1998) reported fetal death and reabsorption, abortion, stillbirth and the birth of live but infected lambs among sheep inoculated with NC-1 strain $N$. caninum at days 45, 65 and 90 of gestation. Koyama et al. (2001) isolated $N$. caninum from the brain of a pregnant sheep. Bishop et al. (2010) found $N$. caninum DNA in the brain and spinal cord of a sheep with severe lesions (multifocal vasculitis and gliosis). In Brazil, Pena et al. (2007) isolated $N$. caninum from the brain of an infected sheep.

Buxton et al. (2001) showed that primary infection in pregnant sheep resulted in loss of all fetuses while inoculation of sheep before pregnancy did not cause mortality and also conferred protection against subsequent challenge during pregnancy.

Otter et al. (1997) and Helmick et al. (2002) found no association or rare involvement of $N$. caninum abortions in sheep, respectively. Spilovska and Reiterova (2008) concluded that the sporadic occurrence of neosporosis in sheep had low impact on economic and reproductive losses. In Brazil, Romanelli et al. (2007) and Soares et al. (2009) found no relationship between seroprevalence of neosporosis and reproductive problems in sheep.

However, many other researchers have observed a correlation between neosporosis and reproductive disorders in sheep (JOLLEY et al., 1999; KOBAYASHI et al., 2001; HASSIG et al., 2003; WEST et al., 2006; HOWE et al., 2008; ASADPOUR et al., 2013).

There are few published data on the seroprevalence of $N$. caninum in sheep. In Brazil, Aguiar et al. (2004) described 29\% of seropositive animals and $60 \%$ of the properties had at least one infected animal. Figliuolo et al. (2004) reported $9.2 \%$ seropositivity. In $86.6 \%$ of the properties, at least one animal was diagnosed positive for $N$. caninum. Vogel et al. (2006) and Romanelli et al. (2007) found $3.2 \%$ and $9.5 \%$ seropositive animals, respectively. Soares et al. (2009) found at least one animal infected with $N$. caninum in $17.1 \%$ of the properties. The seroprevalence was $1.8 \%$. Ueno et al. (2009) observed $8.81 \%$ of infected sheep with N. caninum. Munhoz et al. (2010) observed 13.91\% seropositivity among sheep from 11 properties.

Although some survey regarding neosporosis in sheep have been carried out in Brazil, the state of Santa Catarina lacks epidemiological information about this disease, which should be assessed in sheep flocks, as it is an important activity in the State. The objective of this study was to determine the seroprevalence of Neospora caninum between ewes, on reproductive age, from Santa Catarina Plateau, Brazil.

\section{Material and Methods}

The sheep flock from Santa Catarina Plateau consists of 74,195 animals (IBGE, 2011). The sampling consisted of 1,308 animals, with an expected prevalence of $12 \%, 2.5 \%$ error and $95 \%$ confidence level (EPI-INFO 6.0, 1996).

From april to october of 2012, blood samples were collected from ewes of breeding age $(\geq 18$ months) in the plateau of the state of Santa 
Catarina. The plateau is located in mountain region of the state of Santa Catarina, in southern Brazil at an approximate altitude of $916 \mathrm{~m}$ and with a mean annual temperature of $14.3^{\circ} \mathrm{C}$. It is the most central mesorregion of the state of Santa Catarina, borderline all other mesorregions and consists of thirty municipalities. The samples were tested by IFAT using NC1 strain tachyzoites of $N$. caninum as antigen (DUBEY et al., 1988), according to Conrad et al. (1993) and Paré et al. (1995). Samples that showed titers $\geq 50$ were considered positive (JOLLEY et al., 1999) and these were titrated 2-fold up to a maximum dilution. Positive and negative sera were used as controls.

Information about the animals was obtained through questionnaires to the owners concerning animal management, frequency and type of reproductive disorders in the last 12 months, diet and exposure to dogs, cattle and/or other animals. Data was analyzed by Fisher's exact (R DEVELOPMENT CORE TEAM, 2009) and Chi-Square tests $(\mathrm{P}<0.05)$ in order to correlate the results with the risk factors and/or reproductive disorders.

\section{Results and Discussion}

Among 1,308 animals evaluated in this study, $92(7 \%)$ were infected with $N$. caninum. The titers observed were 50 (20), 100 (27), 200 (15), 400 (15), 800 (10), 1600 (3) and 3200 (2). In 39 (42.4\%) of the 92 properties assessed at least one animal was positive for $N$. caninum (Table 1), with prevalence rates ranging from zero to $40 \%$, which shows the widespread occurrence of coccidiosis among animals at the Plateau of Santa Catarina. AlMajali et al. (2008), Aguiar et al. (2004), Figliuolo et al. (2004), Soares et al. (2009), Faria et al. (2010) and Salaberry et al. (2010) found $45.8 \%, 60 \%$, $86.6 \%, 17.1 \%, 53.8 \%$ and $83.3 \%$ of the properties with animals that tested positive for $N$. caninum, respectively.

The prevalence of $N$. caninum infection observed in this study (7\%) was similar to results from other surveys conducted in Brazil (FIGLIUOLO et al., 2004; ROMANELLI et al., 2007; UENO et al., 2009; SALABERRY et al., 2010; MUNHOZ et al., 2010; FARIA et al., 2010; LANGONI et al., 2011; MACHADO et al., 2011; ANDRADE et al., 2012) and in other countries, such as China (HUI, 2008), Czech Republic (BARTOVA et al., 2009) and Spain (PANADERO et al., 2010), with reported seropositivity rates for $N$. caninum ranging from 8.0 to $13.91 \%$ in the sheep samples analyzed using ELISA or IFAT.

Lower values were reported by Al-Majali et al. (2008), in Jordan (4.3\%, ELISA); Spilovska and Reiterova (2008) in Slovakia (3.7\%); Vogel et al. (2006) in Rio Grande do Sul (3.2\%, ELISA); Soares et al. (2009) in Mossoró, RN (1.8\%, IFAT, 1:50); Suzuki et al. (2011) in Uruguay (0.7\%, ELISA); Moraes et al. (2011) in Maranhão (4.69\%, IFAT) and Rosa et al. (2011) in Lages, SC (5.83\%, IFAT, $1: 50)$.

Aguiar et al. (2004), in Monte Negro-RO, reported $29 \%$ of seropositivity (IFAT, 1:50); Andreotti et al. (2009), comparing the ELISA (based on recombinant protein NcSRS2) and IFAT (1:50), found an occurrence of $32 \%$ and $30.8 \%$, respectively in a flock of Campo Grande, MS; Abo-Shehada and Abu-Halaweh (2010), in Jordan, identified a prevalence of $63 \%$ using ELISA; Rossi et al. (2011), observed a prevalence of $23 \%$ by immunoblot among sheep in Uberlândia, MG; Nasir et al. (2012), in Pakistan, found 27.7\% of infected animals (ELISA) and Tembue et al. (2011), in Pernambuco, found $64.2 \%$ of infected sheep (IFAT, $\geq 1: 50$ ), rates which are significantly higher than those usually observed. 
Table 1. Seropositivity for Neospora caninum (IFAT $\geq 50$ ) in ewes by the municipalities of Santa Catarina Plateau. Lages, SC, 2012.

\begin{tabular}{|c|c|c|c|c|}
\hline Municipality & $\begin{array}{c}\text { Properties } \\
\text { n }\end{array}$ & $\begin{array}{c}\text { Positive Properties } \\
\text { n (\%) }\end{array}$ & $\begin{array}{c}\text { Samples by } \\
\text { municipality }\end{array}$ & $\begin{array}{c}\text { Samples Positive } \\
\text { n (\%) }\end{array}$ \\
\hline Abdon Batista & 1 & 0 & 4 & 0 \\
\hline Anita Garibaldi & 2 & 0 & 29 & 0 \\
\hline Brunópolis & 3 & $2(66.6)$ & 38 & $3(7.9)$ \\
\hline Bocaina do Sul & 2 & $1(50)$ & 28 & $1(3.6)$ \\
\hline Bom Jardim da Serra & 3 & $2(66.6)$ & 38 & $4(10.5)$ \\
\hline Bom Retiro & 3 & $3(100)$ & 62 & $6(9.7)$ \\
\hline Capão Alto & 3 & $1(33.3)$ & 56 & $2(3.6)$ \\
\hline Campo Belo do Sul & 4 & $2(50)$ & 61 & $6(9.8)$ \\
\hline Campos Novos & 6 & $4(66.6)$ & 112 & $19(17)$ \\
\hline Celso Ramos & 1 & 0 & 5 & 0 \\
\hline Cerro Negro & 2 & $1(50)$ & 23 & $1(4.3)$ \\
\hline Correia Pinto & 3 & $1(33.3)$ & 35 & $1(2.9)$ \\
\hline Curitibanos & 7 & $4(57.1)$ & 141 & $12(8.5)$ \\
\hline Frei Rogério & 2 & $2(100)$ & 25 & $3(12)$ \\
\hline Lages & 12 & $3(25)$ & 198 & $10(5.1)$ \\
\hline Monte Carlo & 1 & 0 & 9 & 0 \\
\hline Otacílio Costa & 2 & 0 & 5 & 0 \\
\hline Painel & 4 & $2(50)$ & 62 & $4(6.5)$ \\
\hline Palmeira & 2 & 0 & 20 & 0 \\
\hline Ponte Alta & 3 & 0 & 26 & 0 \\
\hline Ponte Alta do Norte & 2 & $1(50)$ & 20 & $1(5)$ \\
\hline Rio Rufino & 1 & $1(100)$ & 15 & $6(40)$ \\
\hline Santa Cecília & 4 & 0 & 48 & 0 \\
\hline São Cristóvão do Sul & 2 & 0 & 24 & 0 \\
\hline São Joaquim & 5 & $4(80)$ & 95 & $8(8.4)$ \\
\hline São José do Cerrito & 5 & $2(40)$ & 70 & $2(2.9)$ \\
\hline Urubici & 3 & $1(33.3)$ & 26 & $1(3.8)$ \\
\hline Urupema & 2 & 0 & 15 & 0 \\
\hline Vargem & 1 & $1(100)$ & 8 & $1(12.5)$ \\
\hline Zortéa & 1 & $1(100)$ & 10 & $1(10)$ \\
\hline Total & 92 & $39(42.4)$ & 1308 & $92(7)$ \\
\hline
\end{tabular}

An association between the prevalence of $N$. caninum and crossbreed animals $(\mathrm{P}=0.0249)$ was observed. Among positives, $64.1 \%$ were crossbred and these ewes showed seroprevalence 1.65 times greater $(9.9$ versus $6,0 \%)$ than the animals breed (Table 2). Crossbred sheep totaled 974 samples $(74.5 \%)$ and they predominate in the area studied, where most of the properties are small family farms and the sheep industry, which is not the main farm activity, is concurrent with other activities. Faria et al. (2010), in the state of Alagoas, found that properties size $\leq 30$ ha were identified as a risk factor for infection by $N$. caninum in sheep. In this study, the lowest infection rates were observed in flocks belonging to professional farmers, where they raise purebred animals and the sheep industry plays an important economic role (Table 2). In these properties, animal management is more 
appropriate, reducing the contact with sources of $N$. caninum infection. However, Salaberry et al. (2010) found no correlation between breed and
$N$. caninum infection and Nasir et al. (2012), on the contrary, found higher infection prevalence in purebred animals.

Table 2. Prevalence for Neospora caninum (IFAT, $\geq 50$ ) in ewes from Santa Catarina Plateau. Lages, SC, 2012.

\begin{tabular}{|c|c|c|c|c|c|c|c|c|}
\hline \multirow{2}{*}{\multicolumn{2}{|c|}{ Variable }} & \multicolumn{2}{|c|}{ Animals } & \multicolumn{2}{|c|}{ Positive $^{1}$} & \multicolumn{2}{|c|}{ Positive $^{2}$} & \multirow{2}{*}{$\mathbf{P}$} \\
\hline & & $\mathbf{n}$ & $\%$ & $\mathbf{n}$ & $\%$ & $\mathbf{n}$ & $\%$ & \\
\hline \multirow{2}{*}{ Breed } & No defined & 974 & 74.5 & 59 & 6.0 & 59 & 64.1 & \multirow{2}{*}{0.0249} \\
\hline & Defined & 334 & 25.5 & 33 & 9.9 & 33 & 35.9 & \\
\hline \multirow{2}{*}{ Diet } & Pasture & 1050 & 80.3 & 72 & 6.8 & 72 & 78.2 & \multirow{2}{*}{0.5887} \\
\hline & Supplementation & 258 & 19.7 & 20 & 7.8 & 20 & 21.7 & \\
\hline \multirow{3}{*}{$\begin{array}{l}\text { Reproductive } \\
\text { problems }\end{array}$} & Yes & 381 & 29.1 & 15 & 4.0 & 15 & 16.3 & \multirow{3}{*}{0.0041} \\
\hline & No & 917 & 70.1 & 77 & 8.4 & 77 & 83.7 & \\
\hline & Uninformed & 10 & 0.8 & - & - & - & - & \\
\hline \multirow{2}{*}{$\begin{array}{c}\text { Contact with } \\
\text { dogs }\end{array}$} & Yes & 1219 & 93.2 & 84 & 6.9 & 84 & 91.3 & \multirow{2}{*}{0.59} \\
\hline & No & 89 & 6.8 & 8 & 9.0 & 8 & 8.7 & \\
\hline \multirow{3}{*}{$\begin{array}{l}\text { Contact with } \\
\text { cats }\end{array}$} & Yes & 999 & 76.4 & 76 & 7.6 & 76 & 82.6 & \multirow{3}{*}{0.228} \\
\hline & No & 299 & $22 ., 8$ & 16 & 5.3 & 16 & 17.4 & \\
\hline & Uninformed & 10 & 0.8 & - & - & - & - & \\
\hline \multirow{3}{*}{$\begin{array}{l}\text { Contact with } \\
\text { cattle }\end{array}$} & Yes & 1134 & 86.7 & 74 & 6.5 & 74 & 80.4 & \multirow{3}{*}{0.0491} \\
\hline & No & 164 & 12.5 & 18 & 11.0 & 18 & 19.6 & \\
\hline & Uninformed & 10 & 0.8 & - & - & - & - & \\
\hline Total & & 1308 & 100 & 92 & - & 92 & 100 & \\
\hline
\end{tabular}

${ }^{1}$ Relationship between the total number of positive animals per variable and the total number of animals from each variable.

${ }^{2}$ Relationship between total positive animals among each variable and the total number of positive animals.

P: Level descriptive test $\chi 2$.

Although the contact with cattle, which is the natural intermediate host for $N$. caninum, does not necessarily reflect the risk for $N$. caninum infection in sheep, it also showed a correlation with the prevalence of infection $(\mathrm{P}=0.0491)$. Presumably, this correlation can also be attributed to management conditions. Most of the seropositive animals $(80.4 \%)$ were observed in the properties where there was contact between sheep and cattle, which represented $86.7 \%$ of the total flocks assessed (Table 2).
No association was found between serology for $N$. caninum and reproductive disorders. Among the 92 seropositive animals, $77(83.7 \%)$ showed no reproductive problems (Table 2). Among animals with reproductive problems $(\mathrm{n}=381)$, only $15(4 \%)$ were infected with $N$. caninum. However, infected animals by $N$. caninum, with prevalence rates ranging from $3.3 \%$ to $30 \%$, were found in eight of the 24 properties in which reproductive disorders have been reported. Romanelli et al. (2007) and Soares et al. (2009) also found no relationship 
between serology for $N$. caninum and reproductive disorders. Salaberry et al. (2010), in Uberlândia, MG found statistically significant differences in flocks with abortions associated with the occurrence of antibodies against $N$. caninum. The same was observed by Machado et al. (2011) in the state of São Paulo. Pinto et al. (2012), in Brazil, observed the involvement of the $N$. caninum in sheep abortion by immunohistochemistry. Abortion in small ruminants is normally associated with Toxoplasma gondii and the role of $N$. caninum is uncertain. According to Howe et al. (2012), the role of $N$. caninum in reproductive disorders in sheep seems to depend on a multifactorial approach involving serology and fetal tissues and fluids studies for conclusive diagnosis. The same was observed by Moreno et al. (2012).

There were no statistically significant differences between the 30 municipalities of the Santa Catarina Plateau where samples were taken from or between the properties. However, the highest titres (800 to 3200) were observed in concentrated form in five farms from four municipalities. These properties also showed high seropositivity among animals sampled $(22.2 \%$ to $40 \%)$. However, only one of the five properties had the occurrence of abortions and/or stillbirths reported in the 12 months prior to blood collection.

The contact with dogs showed no association with $N$. caninum seropositive, suggesting that vertical transmission might be more common in the flocks assessed. As in the present study only females of breeding age ( $\geq 18$ months) were assessed, a higher occurrence of vertical transmission can be inferred but not proven. In goats, the congenital infection perhaps is one of the main routes of $N$. caninum transmission (MESQUITA et al., 2013). Figliuolo et al. (2004), in the state of São Paulo; Soares et al. (2009), in Mossoró, RN; Salaberry et al. (2010), in Uberlândia, MG; Romanelli et al. (2007), in Guarapuava, PR and Moraes et al. (2011), in
Maranhão, also did not identify contact with dogs as a risk factor for infection by $N$. caninum. In contrast, Munhoz et al. (2010) found an association between the access of dogs to the viscera of sheep and the slaughter of animals within the property with the seropositivity of the flock. Al-Majali et al. (2008), in Jordan, have identified properties with more than one dog as a risk factor, but this association was not observed in this study even though it was common to all properties assessed. Abo-Shehada and Abu-Halaweh (2010) and Machado et al. (2011) identified the presence of dogs in the flock as a risk factor for infection.

Diet was not associated with $N$. caninum infection, even in animals that received some type of supplementation (corn grain, animal feed and corn silage) which are more susceptible to fecal contamination by dogs. Romanelli et al. (2007) did not find an association with the type of diet, but Moraes et al. (2011), in Maranhão, observed a correlation between seropositivity to $N$. caninum in sheep and diet supplementation.

\section{Conclusions}

The present study indicates the presence of $N$. caninum in the sheep flocks of Santa Catarina Plateau and the need to identify the agent in fetal tissues and fluids responsible for ewe abortions to elucidate the role of $N$. caninum in reproductive disorders in this species.

\section{Observations}

This work was assessed and approved by the Ethical Committee leading Research with Human (CEPSH) from UDESC, protocol $n^{\circ}$ 244/2009 on December 17, 2009 and the Ethics Committee in Animal Experimentation (CETEA) from CAV/ UDESC protocol $n^{\circ} 1.35 / 09$ on September 29, 2009. 


\section{References}

ABO-SHEHADA, M. N.; ABU-HALAWEH, M. M. Flock-level seroprevalence of, and risk factors for, Neospora caninum among sheep and goats in northern Jordan. Preventive Veterinary Medicine, Colorado, v. 93, n. 1, p. 25-32, 2010.

AGUIAR, D. M.; CHIEBAO, D. P.; RODRIGUES, A. A. R.; CAVAlCANTE, G. T.; LABRUNA, M. B.; GENNARI, S. M. Anti-Neospora caninum antibodies prevalence in sheep from Monte Negro County, RO, Brazilian Western Amazon. Arquivos do Instituto Biológico, São Paulo, v. 71, p. 616-618, 2004. Supplement.

AL-MAJALI, A. M.; JAWASREH, K. I.; TALAFHA, H. A.; TALAFHA, A. Q. Neosporosis in sheep and different breeds of goats from Southern Jordan: prevalence and risk factors analysis. American Journal of Animal and Veterinary Sciences, New York, v. 3, n. 2, p. 47-52, 2008.

ANDRADE, G. S.; BRUHN, F. R. P.; ROCHA, C. M. B. M.; GUIMARAES, A. S.; GOUVEIA, A. M. G.; GUIMARAES, A. M. Seroprevalence and risk factors for Neospora caninum in sheep in the state Minas Gerais, southeastern Brazil. Veterinary Parasitology, Amsterdam, v. 188, n. 1-2, p. 168-171, 2012.

ANDREOTTI, R.; MATOS, M. F. C.; GONCALVES, K. N.; OSHIRO, L. M.; LIMA JUNIOR, M. S. C.; PAIVA, F.; LEITE, F. L. Comparison of indirect ELISA based on recombinant protein NcSRS2 and IFAT for detection of Neospora caninum antibodies in sheep. Revista Brasileira de Parasitologia Veterinária, Jaboticabal, v. 18, n. 2, p. 19-22, 2009.

ASADPOUR, R.; JAFARI-JOOZANI, R.; SALEHI, N. Detection of Neospora caninum in ovine abortion in Iran. Journal of Parasitic Diseases, New Delhi, v. 37, n. 1, p. 105-109, 2013.

BARTOVA, E.; SEDLAK, K.; LITERAK, I. Toxoplasma gondii and Neospora caninum antibodies in sheep in the Czech Republic. Veterinary Parasitology, Jaboticabal, v. 161, n. 1-2, p. 131-132, p. 2009.

BISHOP, S.; KING, J.; WINDSOR, P.; REICHEL, M. P.; ELLIS, J.; ŚLAPETA, J. The first report of ovine cerebral neosporosis and evaluation of Neospora caninum prevalence in sheep in New South Wales. Veterinary Parasitology, Jaboticabal, v. 170, n. 1-2, p. 137-142, 2010.

BUXTON, D.; MALEY, S. W.; THOMSON, K. K.; TREES, A. J.; INNES, E. A. Experimental infection of non-pregnant and pregnant sheep with Neospora caninum. Journal of Comparative Pathology, Amsterdan, v. 117 , n. 1, p. 1-16, 1997.
BUXTON, D.; MALEY, S. W.; WRIGHT, S.; THOMSON, K. M.; RAE, A. G.; INNES, E. A. The pathogenesis of experimental neosporosis in pregnant sheep. Journal of Comparative Pathology, Amsterdan, v. 118, n. 4, p. 267-279, 1998.

BUXTON, D.; WRIGHT, S.; MALEY, S. W.; RAE, A. G.; LUNDEN, A.; INNES, E. A. Immunity to experimental neosporosis in pregnant sheep. Parasite Immunology, Oxford, v. 23, n. 2, p. 85-91, 2001.

CONRAD, P. A.; SVERLOW, K. W.; ANDERSON, M. L.; ROWE, J.; BONDURANT, R.; TUTER, G.; BREITMEYER, R.; PALMER, C.; THURMOND, M.; ARDANS, A. Detection of serum antibody responses in cattle with natural or experimental Neospora infections. Journal of Veterinary Diagnostic Investigation, Davis, v. 5, n. 4, p. 572-578, 1993.

DUBEY, J. P.; CARPENTER, J. L.; SPEER, C. A.; TOPPER, M. J.; UGGLA, A. Newly recognized fatal protozoan disease of dogs. Journal American Veterinary Medical Association, v. 192, n. 9, p. 1269-1285, 1988.

DUBEY, J. P.; HARTLEY, W. J.; LINDSAY, D. S.; TOPPER, M. J. Fatal congenital Neospora caninum infection in a lamb. Journal of Parasitology, Lawrence, v. 76, n. 1, p. 127-130, 1990.

DUBEY, J. P.; JENKINS, M. C.; RAJENDRAN, C.; MISKA, K.; FERREIRA, L. R.; MARTINS, J.; KWOK, O. C. H.; CHOUDHARY, S. Gray wolf (Canis lupus) is a natural definitive host for Neospora caninum. Veterinary Parasitology, Jaboticabal, v. 181, n. 2-4, p. 382-387, 2011.

DUBEY, J. P.; LINDSAY, D. S. Neospora caninum induced abortion in sheep. Journal of Veterinary Diagnostic Investigation, Davis, v. 2, n. 3, p. 230-233, 1990.

EPI-INFO. Version 6: a word processing, database, and statistics program for public health on IBM-compatible microcomputers. Atlanta: Centers for Disease Control and Prevention, 1996.

FARIA, E. B.; CAVALCANTI, E. F. T. S. F.; MEDEIROS, E. S.; PINHEIRO JUNIOR, J. W.; AZEVEDO, S. S.; ATHAYDE, A. C. R.; MOTA, R. A. Risk factors associated with Neospora caninum seropositivity in sheep from the state of Alagoas, in the northeast region of Brazil. Journal of Parasitology, Lawrence, v. 96, n. 1, p. 197-199, 2010.

FIGLIUOLO, L. P. C.; KASAI, N.; RAGOZO, A. M. A.; PAULA, V. S. O. de; DIAS, R. A.; SOUZA, S. L. P.; GENNARI, S. M. Prevalence of anti-Toxoplasma gondii and anti-Neospora caninum antibodies in ovine from São Paulo State, Brazil. Veterinary Parasitology, Jaboticabal, v. 123, n. 3-4, p. 161-166, 2004. 
GONDIN, L. F. P.; McALLISTER, M. M.; PITT, W. C.; ZEMLICKA, D. E. Coyotes (Canis latrans) are definitive hosts of Neospora caninum. International Journal for Parasitology, Oxford, v. 34, n. 2, p. 159-161, 2004.

HASSIG, M.; SAGER, H.; REITT, K.; ZIEGLER, D.; STRABEL, D.; GOTTSTEIN, B. Neospora caninum in sheep: a herd case report. Veterinary Parasitology, Jaboticabal, v. 117, n. 3, p. 213-220, 2003.

HELMICK, B.; OTTER, A.; MCGARRY, J.; BUXTON, D. Serological investigation of aborted sheep and pigs for infection by Neospora caninum. Research in Veterinary Science, Oxford, v. 73, n. 2, p. 187-189, 2002.

HOWE, L.; COLleTt, M. G.; PATTISON, R. S.; MARSHALL, J.; WEST, D. M.; POMROY, W. E. Potential involvement of Neospora caninum in naturally occurring ovine abortions in New Zealand. Veterinary Parasitology, Jaboticabal, v. 185, n. 2-4, p. 64-71, 2012.

HOWE, L.; WEST, D. M.; COLLETT, M. G.; TATTERSFIELD, G.; PATTISON, R. S.; POMROY, W. E.; KENYON, P. R.; MORRIS, S. T.; WILLIAMSON, N. B. The role of Neospora caninum in three cases of unexplained ewe abortions in the southern North Island of New Zealand. Small Ruminant Research, Amsterdam, v. 75, n. 2-3, p. 115-122, 2008.

HUI, L. X. Serological survey of Neospora caninum infection in sheep from Wulan County, Qinghai Province, China. Chinese Journal of Zoonoses, Fuzhou, v. 24, n. 2, p. 188, 2008.

INSTITUTO BRASILEIRO DE GEOGRAFIA E ESTATÍSTICA - IBGE. Banco de dados agregados: censo agropecuário de 2011. IBGE: Brasília, 2011. Available at: <http://www.sidra.ibge.gov.br/bda/tabela/ listabl.asp? $\mathrm{z}=\mathrm{t} \& \mathrm{c}=73>$. Accessed at: 04 mar. 2012.

JOLLEY, W. R.; MCALLISTER, M. M.; MCGUIRE, A. M.; WILLS, R. A. Repetitive abortion in Neosporainfected ewes. Veterinary Parasitology, Jaboticabal, v. 82, n. 3, p. 251-257, 1999.

KING, J. S.; ŠLAPETA, J.; JENKINS, D. J.; ALQASSAB, S. E.; ELLIS, J. T.; WINDSOR, P.A. Australian dingoes are definitive hosts of Neospora caninum. International Journal of Parasitology, Lawrence, v. 40, n. 8, p. 945-950, 2010.

KOBAYASHI, Y.; YAMADA, M.; OMATA, Y.; KOYAMA, T.; SAITO, A.; MATSUDA, T.; OKUYAMA, K.; FUJIMOTO, S.; FURUOKA, H.; MATSUI, T. Naturally occurring Neospora caninum infection in an adult sheep and her twin fetuses. Journal of Parasitology, Lawrence, v. 87, n. 2, p. 434-436, 2001.

KOYAMA, T.; KOBAYASHI, Y.; OMATA, Y.; YAMADA, M.; FURUOKA, H.; MAEDA, R.; MATSUI,
T.; SAITO, A.; MIKAMI, T. Isolation of Neospora caninum from the brain of a pregnant sheep. Journal of Parasitology, Lawrence, v. 87, n. 6, p. 1486-1488, 2001.

LANGONI, H.; GREGA JUNIOR, H.; GUIMARÃES, F. F.; ULLMANN, L. S.; GAIO, F. C.; UEHARA, R. S.; ROSA, E. P.; AMORIM, R. M.; SILVA, R. C. Serological profile of Toxoplasma gondii and Neospora caninum infection in commercial sheep from São Paulo State, Brazil. Veterinary Parasitology, Amsterdam, v. 177, n. 1-2, p. 50-54, 2011.

MACHADO, G. P.; KIKUTI, M.; LANGONI, H.; PAES, A. C. Seroprevalence and risk factors associated with neosporosis in sheep and dogs from farms. Veterinary Parasitology, Amsterdam, v. 182, n. 2-4, p. 356-358, 2011.

McAlLISTER, M. M.; DUBEY, J. P.; LINDSAY, D. S.; JOLLEY, W. R.; WILLS, R. A.; MCGUIRE, A. M. Dogs are the definitive hosts of Neospora caninum. International Journal of Veterinary Parasitology, Amsterdan, v. 28, n. 9, p. 1473-1478, 1998.

McALLISTER, M. M.; MCGUIRE, A. M.; JOLLEY, W. R.; LINDSAY, D. S.; TREES, A. J.; STOBART, R. H. Experimental neosporosis in pregnant ewes and their offspring. Veterinary Pathology, Amsterdam, v. 33, n. 6, p. 647-655, 1996.

MESQUITA, L. P.; NOGUEIRA, C. I.; COSTA, R. C.; ORLANDO, D. R.; BRUHN, F. R. P.; LOPES, P. F. R.; NAKAGAKI, K. Y. R.; PECONICK, A. P.; SEIXAS, J. N.; BEZERRA JUNIOR, P. S.; RAYMUNDO, D. L.; VARASCHIN, M. S. Antibody kinetics in goats and conceptuses naturally infected with Neospora caninum. Veterinary Parasitology, Amsterdam, v. 196, n. 3-4, p. 327-333, 2013.

MORAES, L. M. B.; RAIMUNDO, J. M.; GUIMARAES, A.; SANTOS, H. A.; MACEDO JUNIOR, G. L.; MASSARD, C. L.; MACHADO, R. Z.; BALDANI, C. D. Occurrence of anti-Neospora caninum and antiToxoplasma gondii $\operatorname{IgG}$ antibodies in goats and sheep in western Maranhao, Brazil. Revista Brasileira de Parasitologia Veterinária, Jaboticabal, v. 20, n. 4, p. 312317, 2011.

MORENO, B.; COLLANTES-FERNANDEZ, E.; VILLA, A.; NAVARRO, A.; REGIDOR-CERRILLO, J.; ORTEGA-MORA, L. M. Occurrence of Neospora caninum and Toxoplasma gondii infections in ovine and caprine abortions. Veterinary Parasitology, Amsterdam, v. 187, n. 1-2, p. 312-318, 2012.

MUGRIDGE, N. B.; MORRISON, D. A.; HECKEROTH, A. R.; JOHSON, A. M.; TENDER, A. M. Phylogenetic analysis based on full-length large subunit ribosomal 
RNA gene sequence comparison reveals that Neospora caninum is more closely related to Hammondia heydorni than to Toxoplasma gondii. International Journal for Parasitology, Oxford, v. 29, n. 10, p. 1545-1556, 1999.

MUNHOZ, K. F.; LUCA NETO, M.; SANTOS, S. M. A.; GARCIA, J. L.; GUIMARAES JUNIOR, J. S.; VIDOTTO, O.; HEADLEY, S. A.; YAMAMURA, M. H. Occurrence of anti-Neospora caninum antibodies in sheep from farms located in northern Paraná, Brazil. Semina: Ciências Agrárias, Londrina, v. 31, n. 4, p. 1031-1039, 2010.

NASIR, A.; ASHRAF, M.; KHAN, M. S.; JAVEED, A.; YAQUB, T.; AVAIS, M.; REICHEL, M. P. Prevalence of Neospora caninum antibodies in sheep and goats in Pakistan. Journal of Parasitology, Lawrence, v. 98, n. 1, p. 213-215, 2012.

OTTER, A.; WILSON, B. W.; SCHOLES, S. F. E.; JEFFREY, M.; HELMICK, B.; TREES, A. J. Results of a survey to determine whether Neospora is a significant cause of ovine abortion in England and Wales. Veterinary Record, London, v. 140, n. 7, p. 175-177, 1997.

PANADERO, R.; PAINCEIRA, A.; LOPEZ, C.; VAZQUEZ, L.; PAZ, A.; DIAZ, P.; DACAL, V.; CIENFUEGOS, S.; FERNANDEZ, G.; LAGO, N.; DIEZ-BANOS, P.; MORRONDO, P. Seroprevalence of Toxoplasma gondii and Neospora caninum in wild and domestic ruminants sharing pastures in Galicia (Northwest Spain). Research in Veterinary Science, Oxford, v. 88, n. 1, p. 111-115, 2010.

PARÉ, J.; HIETALA, S. K.; THURMOND, M. C. Interpretation of an indirect fluorescent antibody test for diagnosis of Neospora sp. infection in cattle. Journal of Veterinary Diagnostic Investigation, Davis, v. 7, n. 2, p. 273-275, 1995.

PENA, H. F. J.; SOARES, R. M.; RAGOZO, A. M. A.; MONTEIRO, R. M.; YAI, L. E. O.; NISHI, S. M.; GENNARI, S. M. Isolation and molecular detection of Neospora caninum from naturally infected sheep from Brazil. Veterinary Parasitology, Amsterdam, v. 147, n. 1-2, p. 61-66, 2007.

PINTO, A. P.; BACHA, F. B.; SANTOS, B. S.; DRIEMEIER, D.; ANTONIASSI, N. A. B.; RIBAS, N. L. K. S.; LEMOS, R. A. A. Sheep abortion associated with Neospora caninum in Mato Grosso do Sul, Brazil. Pesquisa Veterinária Brasileira, Seropédica, v. 32, n. 8 , p. 739-742, 2012.

R DEVELOPMENT CORE TEAM. R: A language and environment for statistical computing. $\mathrm{R}$ Foundation for Statistical Computing, Vienna: 2009. Available at: $<$ http://www. R-project. org > . Accessed at: 04 mar. 2012.
ROMANELLI, P. R.; FREIRE, R. L.; VIDOTTO, O.; MARANA, E. R. M.; OGAWA, L.; PAULA, V. S. O.; GARCIA, J. L.; NAVARRO, I. T. Prevalence of Neospora caninum and Toxoplasma gondii in sheep and dogs from Guarapuava farms, Paraná State, Brazil. Research in Veterinary Science, Oxford, v. 82, n. 2, p. 202-207, 2007.

ROSA, L. D.; MOURA, A. B.; GUTHS, M. F.; BELLATO, V.; SARTOR, A. A.; SOUZA, A. P. Prevalência e fatores de risco para infecção por Neospora caninum em ovinos no município de Lages, Santa Catarina, Brasil. Revista de Ciências Agroveterinárias, Lages, v. 10, n. 2, p. 127 137, 2011.

ROSSI, G. F.; CABRAL, D. D.; RIBEIRO, D. P.; PAJUABA, A. C. A. M.; CORREA, R. R.; MOREIRA, R. Q.; MINEO, T. W. P.; MINEO, J. R.; SILVA, D. A. O. Evaluation of Toxoplasma gondii and Neospora caninum infections in sheep from Uberlândia, Minas Gerais State, Brazil, by different serological methods. Veterinary Parasitology, Amsterdam, v. 175 , n. 3-4, p. 252-259, 2011.

SALABERRY, S. R. S.; OKUDA, L. H.; NASSAR, A. F. C.; CASTRO, J. R.; LIMA-RIBEIRO, A. M. C. Prevalence of Neospora caninum antibodies in sheep flocks of Uberlandia county, MG. Revista Brasileira de Parasitologia Veterinária, Jaboticabal, v. 19, n. 3, p. 148$151,2010$.

SOARES, H. S.; AHID, S. M. M.; BEZERRA, A. C. D. S.; PENA, H. F. J.; DIAS, R. A.; GENNARI, S. M. Prevalence of anti-Toxoplasma gondii and anti-Neospora caninum antibodies in sheep from Mossoró, Rio Grande do Norte, Brazil. Veterinary Parasitology, Amsterdam, v. 160, n. 3-4, p. 211-214, 2009.

SPILOVSKA, S.; REITEROVA, K. Seroprevalence of Neospora caninum in aborting sheep and goats in the Eastern Slovakia. Folia Veterinaria, Bruxelles, v. 52, n. 1, p. 33-35, 2008.

SUZUKI, K.; CORVA, S. G.; TRAVERIA, G.; CATTANEO, M.; PUENTES, R.; MARTINICORENA, M.; MORENO, J.; FURTADO, A.; FREYRE, A.; SATRAGNO, D.; ACEVEDO, C.; NUNEZ, R.; BERMUDEZ, J. Seroprevalence of Toxoplasma gondii and Neospora caninum in sheep in Uruguay. Analecta Veterinaria, La Plata, v. 31, n. 2, p. 28-32, 2011.

TEMBUE, A. A. S. M.; RAMOS, R. A. N.; SOUSA, T. R.; ALBUQUERQUE, A. R.; COSTA, A. J.; MEUNIER, I. M. J.; FAUSTINO, M. A. G.; ALVES, L. C. Serological survey of Neospora caninum in small ruminants from Pernambuco State, Brazil. Revista Brasileira de Parasitologia Veterinária, Jaboticabal, v. 20, n. 3, p. 246248, 2011. 
UENO, T. E. H.; GONCALVES, V. S. P.; HEINEMANN, M. B.; DILLI, T. L. B.; AKIMOTO, B. M.; SOUZA, S. L. P.; GENNARI, S. M.; SOARES, R. M. Prevalence of Toxoplasma gondii and Neospora caninum infections in sheep from Federal District, central region of Brazil. Tropical Animal Health and Production, New York, v. 41, n. 4, p. 547-552, 2009.
VOGEL, F. S. F.; ARENHART, S.; BAUERMANN, F. V. Antibodies to Neospora caninum in cattle, sheep and water buffalo in Rio Grande do Sul state, Brazil. Ciência Rural, Santa Maria, v. 36, n. 6, p. 1948-1951, 2006.

WEST, D. M.; POMROY, W. E.; COLLETT, M. G.; HILL, F. I.; RIDLER, A. L.; KENYON, P. R.; MORRIS, S. T.; PATTISON, R. S. A possible role for Neospora caninum in ovine abortion in New Zealand. Small Ruminant Research, Amsterdam, v. 62, n. 1-2, p. $135-$ 138, 2006. 